\title{
SCHIMBĂRILE ÎN SPERANȚA DE VIAȚĂ SUB INFLUENȚA PANDEMIEI COVID-191
}

\author{
Vitalie ȘTîRBA (C) ${ }^{2}$, cercetător științific, \\ INCE, Centrul de Cercetări Demografice, Republica Moldova
}

DOI: https://doi.org/10.36004/nier.cdr.2021.15-07

\begin{abstract}
This article highlights the changes in life expectancy in Moldova under the influence of the COVID-19 pandemic. The results show a decrease in life expectancy in 2020, compared to 2019, by 0.9 years in males and 1.3 years in females. The increase in mortality has been particularly pronounced in the ages above 55 and 40 for males and females, respectively. The observed rise in the number of deaths occurred as a result of joint factors, such as the increasing number of persons diagnosed with COVID-19, postponement of planned treatments for the patients with chronic diseases, overloading of the medical system during the pandemic, etc. During the period of self-isolation and a decrease in economic activities, a decrease in mortality caused by external factors could be observed, which contributed to the increase in the life expectancy components among the young population.
\end{abstract}

Cuvinte-cheie: mortalitate, speranța de viață, pandemia COVID-19

Clasificare JEL: J0, I1

În anul 2020, situația pandemică generată de sindromul respirator acut SARS-CoV-2 s-a reflectat asupra schimbărilor în structura mortalității și a creat provocări în domeniul sănătății populației în majoritatea statelor. Principalii factori care au determinat creșterea mortalității sunt consecința răspândirii virusului în rândul populației și a gradului de suprasolicitare a sistemului medical, creând dificultăți în acordarea în deplină măsură a serviciilor medicale pentru persoanele diagnosticate cu COVID-19, dar și celor ce efectuează tratament planificat. Această perioadă a condiționat unele schimbări comportamentale, care se răsfrâng asupra sănătății populației prin creșterea sau descreșterea morbidității și mortalității, având în vedere riscurile de accidentare sau de cronicizare a bolilor. În perioada de autoizolare, unele straturi ale populației s-au confruntat cu schimbări comportamentale, precum: descreșterea activității fizice cauzată de modul sedentar de viață, schimbări în nutriție, consumul de alcool și tutun etc. Totodată, perioada de autoizolare poate determina reducerea incidenței traumatismelor și deceselor violente, inclusiv celor rezultate în urma accidentelor rutiere.

Surplusul de decese în perioada pandemică a contribuit la reducerea speranței de viață în majoritatea statelor (Marois, Muttarak, \& Scherbov, 2020). Comparativ cu statele din Europa de Vest, țările est-europene au

\footnotetext{
${ }^{1}$ Articolul este elaborat în cadrul Programului de Stat (2020-2023) 20.80009.0807.21

"Migrația, schimbări demografice și politici de stabilizare a situației".

2 (C) Vitalie Ștîrba, vitalie.stirba@gmail.com.
} 
înregistrat o diminuare mult mai accentuată a speranței de viață atât la bărbați, cât și la femei (Aburto și alții, 2021a). Totodată, bărbații și femeile au evidențiat o diferențiere în schimbările structurii mortalității în perioada pandemică (Aburto și alții, 2021b). Efectele autoizolării în perioada pandemiei COVID-19 s-au reflectat asupra sănătății persoanelor cu boli cronice, care necesită vizite regulare la medicul de profil (Saqib și alții, 2020), dar totodată au influențat schimbările de nutriție și stilul de viață (Renzo și alții, 2020).

Acest articol pune în evidență schimbările în ceea ce privește speranța de viață din perioada pandemiei COVID-19 ca rezultat al transformărilor din structura mortalității. Datele privind distribuția numărului populației și deceselor pe vârste au fost obținute din surse oficiale (Banca de date BNS; WHO Mortality Database) și alternative (Penina, Jdanov, \& Grigoriev, 2015). Pentru calcularea mortalității standardizate a fost utilizat Noul standard european al populației. Decompoziția speranței de viață a fost efectuată prin metoda lui Andreev, utilizând tabelele de mortalitate prescurtate cu ultima grupă de vârstă $85+$.

În perioada 2000-2020, rata mortalității standardizate în Moldova a cunoscut o descreștere graduală la ambele sexe, înregistrând către 2019 25,6 decese la 1000 populație la bărbați și 16,7 decese la 1000 populație la femei. Această tendință de descreștere a mortalității a fost întreruptă în 2020, când numărul de decese la 1000 populație a crescut la 28,8 la bărbați și 18,7 la femei, ceea ce corespunde valorilor înregistrate în anul 2012.

Creșterea mortalității standardizate din anul 2020 derivă din schimbările în distribuția deceselor pe grupe de vârstă ale populației. În timp ce în populația tânără, atât la bărbați, cât și la femei, intensitatea mortalității a cunoscut o descreștere, în mare parte datorită evitării cauzelor externe de deces, în grupurile de vârstă adulte (50+ ani), numărul de decese a cunoscut o creștere considerabilă comparativ cu anii precedenți.

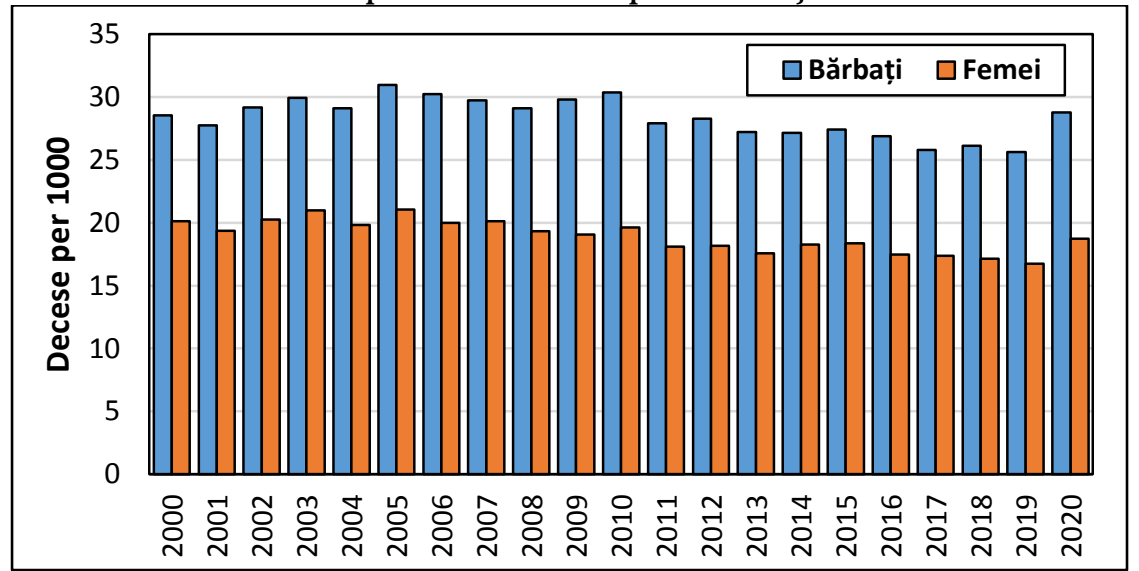

Figura 1. Rata mortalitătiii standardizate în Moldova pentru bărbați și femei, 2000-2020.

Sursa: Calculele autorului în baza datelor Organizației Mondiale a Sănătății (WHO Mortality Database) și Biroului Național de Statistică (Banca de date BNS) 
Între anii 2000 și 2010 dinamica speranței de viață în Moldova a cunoscut o perioadă de stagnare și ușoară fluctuație, înregistrând o medie de 63,4 ani la bărbați și 71,6 ani la femei, urmată de o creștere constantă până în 2019 cu circa 3,5 ani la ambele sexe. În 2020 speranța de viață în Moldova a cunoscut un declin semnificativ comparativ cu anul 2019 (-0,9 ani la bărbați și -1,3 ani la femei), înregistrând valori similare anilor 2015-2016 (Figura 1). Aceste schimbări din speranța de viață derivă din creșterea mortalității din perioada de referință, în care a crescut semnificativ numărul de decese, în special al celor cauzate de sindromul respirator acut SARS-CoV-2, adesea însoțite de unele comorbidități (boli ale sistemului circulator, cancer, diabet zaharat etc.), dar și rezultate în urma suprasolicitării sistemului medical sau imposibilităţii efectuării tratamentului planificat la persoanele cu boli cronice.

În condițiile situației epidemiologice, descreșterea în speranța de viață nu a putut fi prevenită, inclusiv de spectrul de politici implementate pe domeniul sănătății populației, inclusiv: programul de cardiologie intervențională, politicile de control asupra tutunului și alcoolului, programe de prevenire a bolilor cardiovasculare, traumatismelor etc. În acest sens, descreșterea mortalității datorată respectivelor programe pe domeniul sănătății nu a putut compensa pierderile cauzate de numărul de decese din perioada pandemică.

În decursul pandemiei COVID-19, diminuarea activității economice și perioadele de autoizolare a populației au redus numeric accidentările și decesele violente, în care în mai mare măsură este implicată populația tânără și cea aptă de muncă. În același timp, schimbările în modul de viață pe perioada de autoizolare pot influența sănătatea populației pe termen mediu și lung.

Descreșterea speranței de viață înregistrată în anul 2020 reprezintă diferența dintre numărul mediu de ani de viață obținuți în urma descreșterii mortalității prin intermediul politicilor implementate pe domeniul sănătății populației (inclusiv deceselor cauzate de factorii externi) și creșterii numărului de decese sub influența pandemiei COVID-19.

Durata pandemiei cauzate de COVID-19 poate menține mortalitatea la nivelul înregistrat în 2020 sau influența asupra creșterii acesteia în 2021 și pe parcursul perioadei ulterioare. Impactul sindromului respirator acut SARSCoV-2 asupra sănătății populației se reflectă nu doar prin intensitatea mortalității înregistrate, ci și prin creșterea morbidității prin boli cronice rezultate în urma tratamentului de COVID-19, precum și în lipsa acestuia. Complicațiile obținute în urma îmbolnăvirii, dar și schimbările în modul de viață pot influența asupra schimbărilor în structura mortalității din următorii ani și influența asupra duratei medii a vieții în rândul populației. 


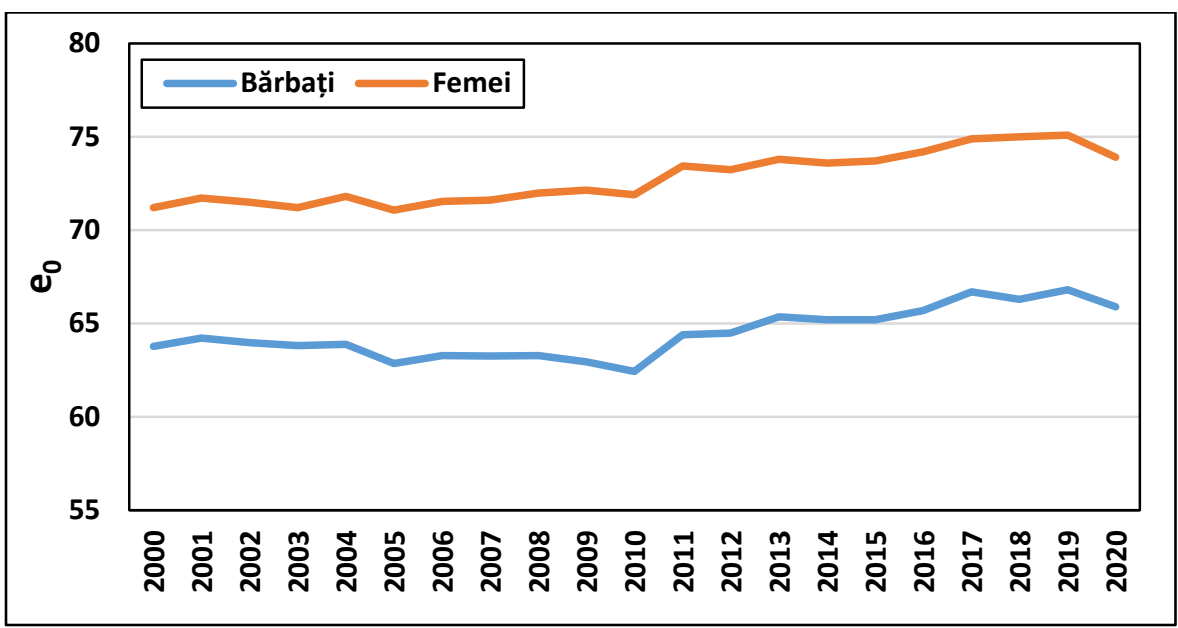

Figura 2. Speranța de viață la naștere pentru bărbați și femei, Moldova, 2000-2020.

Sursa: Biroul Național de Statistică (Banca de date BNS) și (Penina, Jdanov, \& Grigoriev, 2015)

Descreșterea speranței de viață din anul 2020 derivă din schimbările în intensitatea mortalității, care înregistrează valori diferite în rândul populației în dependență de statutul social, locul de trai, dar și alte caracteristici socioeconomice și demografice. În condițiile răspândirii sindromului respirator acut SARS-CoV-2 în rândul populației, dar și având în vedere provocările rezultate în perioada pandemică, distribuția deceselor după cauze a suferit transformări în anumite grupuri de vârstă la bărbați și femei.

În 2020, unele grupuri de vârstă tinere au cunoscut o ușoară diminuare a mortalității, ceea ce a contribuit la creșterea speranței de viață la bărbați și femei cu circa 0,1 ani. Programele pe domeniul sănătății populației, dar și condițiile de autoizolare au contribuit la evitarea deceselor, inclusiv în rândul populației adulte, însă acestea nu au putut compensa pierderile cauzate de surplusul de decese din perioada pandemică.

Creșterea mortalității din 2020 a contribuit la diminuarea speranței de viață cu 0,9 ani la bărbați și 1,3 ani la femei și a fost caracteristică grupurilor de vârstă 40+ ani, la care această descreștere a constituit $-0,85$ ani și respectiv $-1,25$ ani. Distribuția deceselor excesive în populația adultă evidențiază o diferențiere în dependență de sex, la bărbați fiind concentrate între vârstele 60-79 de ani, în timp ce la femei aceste pierderi sunt practic uniform repartizate între vârstele 40-70 și ușor descrescând pentru vârstele 80+. Grupurile respective de vârstă sunt cele mai vulnerabile în contextul situației epidemiologice, având în vedere prevalența bolilor cronice în rândul acestei populații. Totodată, asupra nivelului mortalității din aceste grupuri de vârstă a influențat inclusiv gradul de accesibilitate la serviciile medicale în contextul tratamentului planificat în rândul persoanelor cu boli ale sistemului circulator, cancer etc. 


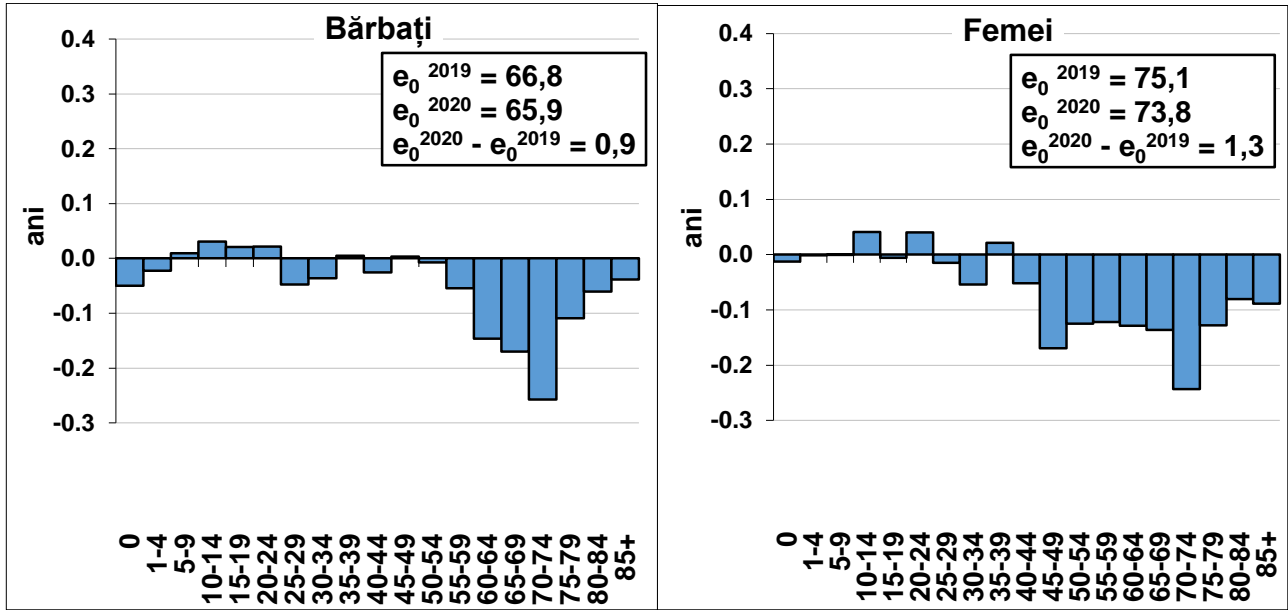

Figura 3-4. Contribuția mortalității în diferența speranței de viață la naștere pentru bărbați și femei între 2019 și 2020, Moldova.

Sursa: Calculele autorului în baza datelor Organizației Mondiale a Sănătății (WHO Mortality Database) și Biroului Național de Statistică (Banca de date BNS)

Rezultatele acestui studiu evidențiază schimbările mortalității și impactul acesteia asupra speranței de viață sub influența pandemiei COVID19. În anul 2020, speranța de viață a înregistrat o descreștere de 0,9 ani la bărbați și 1,3 ani la femei comparativ cu anul 2019. Diminuarea acestui indicator rezultă din creșterea mortalității cauzate de COVID-19, dar și unor provocări din sistemul medical, inclusiv prin amânarea tratamentelor planificate pentru persoanele cu boli cronice, dar și gradului de suprasolicitare a serviciilor medicale în perioada pandemică.

Perioada de autoizolare a populației și de descreștere a activității economice a contribuit la o reducere a mortalității prin cauzele externe de deces în mare parte în rândul grupurilor de vârstă tinere. Totodată, în perioada respectivă, instituțiile de resort au continuat implementarea politicilor pe domeniul sănătății populației și lărgirea spectrului de servicii medicale, ceea ce a contribuit la evitarea și amânarea unor decese, care însă nu au compensat pierderile în numărul de decese cauzate de pandemia COVID19.

Având în vedere că situația epidemiologică nu este ameliorată, în anul 2021 surplusul de decese cauzat de COVID-19 continuă să înregistreze valori mai ridicate față de perioada prepandemică. Numărul excedent de decese din perioada pandemică creează pierderi semnificative în ani de viață, iar complicațiile rezultate în urma răspândirii sindromului respirator acut SARSCoV-2 în rândul populației pot duce la creșterea morbidității și influența calitatea vieții. 


\section{Referințe}

Aburto, J., Kashyap, R., Schöley, J., Angus, C., Ermish, J., Mills, M., \& Dowd, J. (2021b). Estimating the burden of the COVID-19 pandemic on mortality, life expectancy and lifespan inequality in England and Wales: a population-level analysis. $J$ Epidemiol Community Health, 75:735-740. doi:http://dx.doi.org/10.1136/jech-2020-215505

Aburto, J., Scholey, J., Kashnitsky, I., Zhang, L., Rahal, C., Missov, T., . . Kashyap, R. (2021a). Quantifying impacts of the COVID-19 pandemic through lifeexpectancy losses: a population-level study of 29 countries. International Journal of Epidemiology, 1-12. doi: 10.1093/ije/dyab207

Banca de date BNS. (fără an). Preluat de pe https://statistica.gov.md/pageview.php?l=ro\&idc $=407$

Marois, G., Muttarak, R., \& Scherbov, S. (2020). Assessing the potential impact of COVID-19 on life expectancy. PLoS ONE , 15(9), e0238678. doi:https://doi.org/10.1371/journal.pone.0238678

Penina, O., Jdanov, D., \& Grigoriev, P. (2015). Producing reliable mortality estimates in the context of distorted population statistics: the case of Moldova. MPIDR Working Paper WP-2015-011. doi:10.4054/MPIDR-WP-2015-011

Renzo, L., Gualtieri, P., Pivari, F., Soldati, L., Attina, A., Cinelli, G., . . Lorenzo, A. (2020). Eating habits and lifestyle changes during COVID-19 lockdown: an Italian survey. Journal of Translational Medicine, 18:229. doi:https://doi.org/10.1186/s12967-020-02399-5

Saqib, M., Siddiqui, S., Qasim, M., Jamil, M., Rafique, I., Awan, U., . . Afzal, M. (2020). Effect of COVID-19 lockdown on patients with chronic diseases. Diabetes \& Metabolic Syndrome: Clinical Research \& Reviews, 14(6), 1621-1623. doi:https://doi.org/10.1016/j.dsx.2020.08.028

WHO Mortality Database. (fără an). Preluat de pe https://www.who.int/data/datacollection-tools/who-mortality-database 